Revista Tecné, Episteme y Didaxis: TED. Año 2014, Número Extraordinario. ISSN Impreso: 0121-3814, ISSN web: 2323-0126

Memorias, Sexto Congreso Internacional sobre Formación de Profesores de Ciencias. 08 al 10 de octubre de 2014, Bogotá

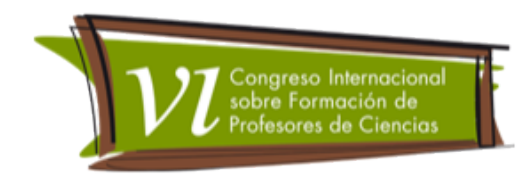

\title{
Leitura de imagens no ensino de Ciências: formulação e circulação de sentidos
}

Moraes, João Carlos Pereira'; Barbosa, Alessandro Tomaz²

Categoria 1: Reflexões e experiências de inovação na sala de aula.

\section{Resumo}

Este trabalho tem por finalidade discutir no âmbito da Análise de Discurso (escola francesa), perspectivas voltadas a leitura de imagem (fotográfica, artística, gráfica, etc) no ensino de Ciências. Percebe-se nas aulas de Ciências que a imagem pode ser lida de diferentes formas pelos estudantes. Suas possibilidades de leitura no ensino de Ciênciasconfirma que a linguagem não é transparente. Nesse artigo, defendemos que a imagem se constitui em texto (unidade a nível do imaginário) e discurso (efeitos de sentidos entre interlocutores). Portanto, ressaltamos a importância dos professores considerarem durante o planejamento de atividades relacionadas aleitura de imagem, que esse processo é bastante complexo e não linear, ou seja, a relação entre o sujeito-leitor e a imagem não é nem direta, nem mecânica.

\section{Palavras-Chave}

Análise de Discurso, funcionamento da linguagem, leitura.

\section{Objetivos}

Partindo de que a interpretação das imagens pressupõe a relação com a cultura, o social, o histórico e a formação social dos sujeitos, esse trabalho, temcomo objetivo discutir no âmbito da Análise de Discurso (escola francesa), perspectivas voltadas a leitura de imagens (fotográfica, artística, gráfica, etc) no ensino de Ciências.

\section{Introdução}

\footnotetext{
1 Mestrando do programa de pós-graduação em Educação científica e Tecnológica/Universidade Federal de Santa Catarina -judkson@gmail.com

2 Mestrando do programa de pós-graduação em Educação científica e Tecnológica/Universidade Federal de Santa Catarina -alessandro.tomaz3@gmail.com
} 
Revista Tecné, Episteme y Didaxis: TED. Año 2014, Número Extraordinario. ISSN Impreso: 0121-3814, ISSN web: 2323-0126

Memorias, Sexto Congreso Internacional sobre Formación de Profesores de Ciencias. 08 al 10 de octubre de 2014, Bogotá

No ensino de Ciências frequentemente são planejadas atividades que envolvem imagens (fotográficas, fílmica), durante a operacionalização em sala de aula,observa-se que as imagens passam por diferentes interpretações.

Segundo Silva, Zimmermann, Carneiro, Gastal e Cassiano(2006), pesquisas têm mostrado que a leitura de imagens precisa ser ensinada, pois elas não são transparentes. Como qualquer outro recurso, o professor tem um papel, intencional ou não, direto ou indireto, no modo como as imagens funcionam em sala de aula.

Percebe-se no ensino de ciências que as imagens podem ser lidas de diferentes formas. As possibilidades de sua leitura confirmam a não transparência da linguagem.Nesse artigo, defendemos que a imagem se constitui em texto e discurso.

- Imagem como discurso: A leitura da imagemproporciona efeitos de sentidos entre interlocutores.

- Imagem como texto: A imagem como uma unidade a nível do imaginário.

\section{Imagem e discurso}

Na perspectiva da Análise de Discurso (AD) linha francesa o discurso se dá na mediação entre interlocutores (rompe com o modelo emissor-receptor). Ao citarmos o termo discurso nos referimos ao "efeito de sentidos entre interlocutores" (Pêcheux, 2006).

Segundo Orlandi (1996):

Falar em discurso é falar em condições de produção e, em relação a essas condições gostaríamos de destacar que, como exposto por Pêcheux (1979), são formações imaginárias, e nessas formações contam a relação de sentido (o coro de vozes, a intertextualidade, a relação que existe entre um discurso e outros) - (pág. 158).

Nessa perspectiva, o discurso é um processo contínuo que não se esgota em uma situação particular. Outras coisas foram ditas antes e outras serão ditas depois. $O$ 
Revista Tecné, Episteme y Didaxis: TED. Año 2014, Número Extraordinario. ISSN Impreso: 0121-3814, ISSN web: 2323-0126

Memorias, Sexto Congreso Internacional sobre Formación de Profesores de Ciencias. 08 al 10 de octubre de 2014, Bogotá

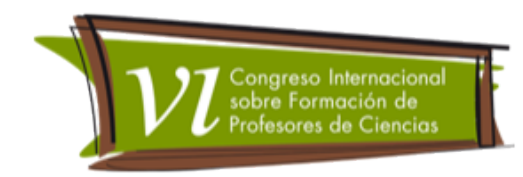

que temos são sempre "pedaços", "trajetos", estados do processo discursivo (Orlandi, 2008, p. 14).Desta forma, consideramos a leitura de imagem no ensino de ciências como discurso, pois durante a interação aluno-imagem são produzidos sentidos que caminham em várias direções.

Ao nos apoiarmos na AD, reconhecemos a impossibilidade de ter acesso a um sentido escondido em algum lugar atrás do texto (ORLANDI, 2008). Para essa autora, o sentido torna-se a questão da própria materialidade do texto, de seu funcionamento, de sua historicidade, dos mecanismos e dos processos de significação.

A AD não é um método de interpretação, não atribui nenhum sentido ao texto. $O$ que ela faz é problematizar a relação com o texto, procurando apenas explicitar os processos de significação que nele estão configurados, os mecanismos de produção de sentidos que estão funcionando (Orlandi, 2012a).

Nessa perspectiva, Orlandi (2012b) enfatiza que o sentido não existe em si, mas é determinado pelas posições ideológicas colocada em jogo no processo sóciohistórico em que as palavras são produzidas. As palavras mudam de sentido segundo as posições daqueles que as empregam. Assim, não há "o sentido da imagem". O sentido é construído a partir do funcionamento da linguagem, considerando os sujeitos envolvidos e as condições em que ocorre sua produção, as quais incluem, de modo geral, a situação imediata e o contexto históricosocial mais amplo.

Nessa direção, os sentidos atribuídos a uma imagem devem-se às distintas condições de produção e podem ser referidos a diferentes formações discursivas. Orlandi (2012c, p. 43) define a formação discursiva como "aquilo que numa formação ideológica dada - ou seja, a partir de uma posição dada em uma conjuntura sócio-histórica dada - determina o que pode e deve ser dito". Por exemplo, a palavra "terra" não significa o mesmo para um índio e para um grande proprietário rural.

Segundo Silva et al.(2006, grifo dos autores), a partir de diferentes formações discursivas, uma mesma imagem pode significar de diferentes modos. Assim, o sujeito não é o centro ou origem do processo de produção de sentidos, mas parte de um processo que se iniciou antes. 
Revista Tecné, Episteme y Didaxis: TED. Año 2014, Número Extraordinario. ISSN Impreso: 0121-3814, ISSN web: 2323-0126

Memorias, Sexto Congreso Internacional sobre Formación de Profesores de Ciencias. 08 al 10 de octubre de 2014, Bogotá

Orlandi (2012c) cita que os sentidos não nascem ab initio. São criados. Sendo assim, a compreensão das imagens não é imediata, e seu uso no contexto pedagógico da sala de aula exige que o professor saiba como fazê-lo, sugere-se que ele planeje uma aula, expondo o processo de textualização, ou seja, como os discursos se materializaram na imagem em questão.

\section{Imagem e texto}

Partindo do processo de textualização, compreendemos que aformulação da imagem é resultado da passagem da dispersão (discurso) para unidade a nível de imaginário (texto).

Na perspectiva da AD, o texto não é a soma de frases e não é fechado em si mesmo. O texto se constitui de enunciados, que marcam as diferentes posições do sujeito. Segundo Orlandi (2008) o texto é uma unidade a nível do imaginário. Essa autora tem proposto o texto como unidade fundamental da linguagem.

Conforme Orlandi (2012b) um texto ao ser inscrito é construído um leitor virtual, um leitor que é constituído no próprio ato da escrita. Em termos do que denominamos "formações imaginárias" em AD, trata-se aqui do leitor imaginário, aquele que o autor imagina (destina) para seu texto e para quem ele dirige. A questão é que existe o leitor virtual (imaginado pelo autor) e um leitor real. No conflito entre esses leitores, resulta uma leitura parafrástica ou uma leitura polissêmica.

Nessa direção, podemos dizer que a atribuição de sentidos a imagemno ensino de Ciências pode variar amplamente desde o que denominamos leitura parafrástica, caracterizada pelo reconhecimento (reprodução) de um sentido que se supõe ser o da imagem (dado pelo autor), e o que denominamos leitura polissêmica, que se define pela atribuição de múltiplos sentidos.

\section{Leitura de imagens no ensino de Ciências}

Nessa perspectiva, consideramos a complexa relação autor, leitor e texto, negar essa relação, levanta a possibilidade de pensar um autor onipotente que controla todo percurso de significação do texto, a transparência do texto e um leitor onisciente com capacidade de dominar as múltiplas determinações de sentidos que jogam em um processo de leitura. Essa perspectiva emite uma visão de que a imagem tem um sentido e os professores devem extrair esse sentido e trabalhar nas aulas de Ciências. Na perspectiva da AD, isto seria uma forma de 
Revista Tecné, Episteme y Didaxis: TED. Año 2014, Número Extraordinario. ISSN Impreso: 0121-3814, ISSN web: 2323-0126

Memorias, Sexto Congreso Internacional sobre Formación de Profesores de Ciencias. 08 al 10 de octubre de 2014, Bogotá

reducionismo linguístico, ou seja, a linguagem como apenas transmissão de informação (Orlandi, 2012b).

Se opondo a isso, lançamos mão da relação existente entre autor/leitor/texto e do conceito de não transparência da linguagem na leitura de imagens no ensino de Ciências. Destacamos que as leituras realizadas em sala de aula sobre imagem pode ser um processo bastante complexo que envolve muito mais que habilidades que se resolvem no imediatismo da ação de ler, ou seja, o aluno não interage apenas com a imagem (relação sujeito/objeto), mas com outro(s) sujeito(s) (leitor virtual, autor, outros textos e etc).

Ao considerarmos a leitura como um processo, é preciso levar em conta as outras possiveis interpretações, pois ela só acontece durante a interação entre o sujeito e o texto e depende das condições de produção dessa leitura (Cassiani-Souza, 2006).

Para Orlandi (2012b) toda leitura tem sua história (as histórias das leituras do texto e a do leitor), sendo assim, apesar de existir leituras previstas para um texto (imagem), vários elementos podem influenciar na previsibilidade dessas leituras. Por exemplo:a intertextualidade (texto tem relação com outros textos).

Orlandi (1984) destaca que todo sujeito-leitor tem sua história de leitura:

O conjunto de leituras feitas configura, em parte, a compreensibilidade de cada leitor específico. Leituras já feitas configuram - dirigem, isto é, podem alargar ou restringir a compreensão do texto de um dado leitor, o que coloca também para a história do leitor, tanto a sedimentação de sentidos como a intertextualidade, como fatores constitutivos de sua produção. (pág. 8).

Apesar de considerar a leitura polissêmica (possibilidade da multiplicidade de sentidos), por outro lado, há a sedimentação histórica dos sentidos em termos de sua dinâmica, isto é, em condições de produção determinada um sentido adquire estatuto dominante em relação aos outros.

$\mathrm{Na}$ interação estabelecida pela leitura de imagens no ensino de Ciências, embora haja possibilidade de múltiplos sentidos, de fato não podemos desconhecer que, enquanto parte do funcionamento social geral, as situações 
Revista Tecné, Episteme y Didaxis: TED. Año 2014, Número Extraordinario. ISSN Impreso: 0121-3814, ISSN web: 2323-0126

Memorias, Sexto Congreso Internacional sobre Formación de Profesores de Ciencias. 08 al 10 de octubre de 2014, Bogotá

de linguagem são reguladas: não se diz o que se quer, em qualquer situação, como também não se pode entender o que se quer, de qualquer maneira, em qualquer situação. Do reconhecimento dessa duplicidade da linguagem (a variação e a regra) decorre a polarização constante entre processo polissêmico e processo parafrástico (Orlandi, 2012c).

Ao buscarmos compreender a leitura de imagens na aula de Ciências, reforçamos que os sentidos produzidos durante a interação autor-imagem-leitor faz parte de um processo que resulta na circulação de vários sentidos que nem sempre condiz com o que foi formulado pelo autor.

Ao nos apoiarmos na $A D$ consideramos que todo texto em relação à leitura teria vários pontos de entrada e vários pontos de fuga.

Segundo Orlandi (2012b) os pontos de entrada correspondem a múltiplas posições do sujeito. Enquanto que os pontos de fuga são as diferentes perspectivas de atribuição de sentidos, ao relacionar-se com os vários pontos de entrada, o leitor pode produzir leituras que se encaminham em várias direções. Não necessariamente previstas, nem organizadas.

Para essa autora, os pontos de entrada são efeitos da relação do sujeito-leitor com a historicidade do texto. Os pontos de fuga são o percurso da historicidade do leitor em relação ao texto, assim, podemos dizer que os sentidos não caminham em linha reta. Eles saem da linha.

\section{Considerações finais}

Consideramos que durante a leitura de imagens, o que temos são efeitos de sentidos entre interlocutores. Daí é que decorre o que se pode chamar de "efeito leitor". A noção de efeito supõe, entre outras coisas, a relação de interlocução na construção de sentidos durante a interação aluno e imagem no ensino de Ciências.

Portanto, ressaltamos a importância dos professores de Ciências considerarem durante o planejamento de atividades relacionadas aleitura de imagens que a linguagem não é transparente, sendo que esse processo ébastante complexo e não linear, ou seja, a relação entre o sujeito-leitor e a imagem não é, pois, nem direta nem mecânica. 
Revista Tecné, Episteme y Didaxis: TED. Año 2014, Número

Extraordinario. ISSN Impreso: 0121-3814, ISSN web: 2323-0126

Memorias, Sexto Congreso Internacional sobre Formación de Profesores de Ciencias. 08 al 10 de octubre de 2014, Bogotá

\section{Referências bibliográficas}

Cassiani-Souza, S. (2003). Repensando a leitura na educação em ciências: necessidade e possibilidade na formação inicial de professores. In: IV Encontro Nacional de Pesquisa em Educação em Ciências.

Orlandi, E. P. (1984). As histórias das leituras.Leitura: Teoria \& Prática, n. 1, pág. 7 9.

Orlandi, E. P. (1996). A linguagem e seu funcionamento - As formas do discurso (4a ed.). Campinas, SP: Pontes.

Orlandi, E. P. (2008). Discurso e texto: formulação e circulação dos sentidos. Campinas, SP: Pontes.

Orlandi, E. P. (2012a). Interpretação: autoria, leitura e efeitos do trabalho simbólico (6a ed.). Campinas, SP: Pontes.

Orlandi, E. P. (2012b). Discurso e leitura (9a ed.).Campinas: Cortez.

Orlandi, E. P. (2012c). Análise de discurso: Princípios e procedimentos (10a ed.). Campinas, SP: Pontes,

Pêcheux, M. (2006). O Discurso: estrutura ou acontecimento (4a ed.). Campinas: Pontes,

Silva, H. C., Zimmermann, E. Carneiro, M. H. S., Gastal, M. L., \& Cassiano, W. S. (2006). Cautela ao usar imagens em aulas de ciências. Ciência \& educação, v. 12, n. 2, pág. 219-233. 